\title{
Management of Stem Rot Disease of Paddy Using Fungicides
}

\author{
D. Pramesh ${ }^{1,2 *}$, Saddamhusen Alase ${ }^{1,2}$, K.M. Muniraju ${ }^{1,2}$ and M. Kirana Kumara ${ }^{1,2}$ \\ ${ }^{1}$ All India Coordinated Rice Improvement Programme, Agricultural Research Station, \\ Gangavathi-583 227, Karnataka, India \\ ${ }^{2}$ Department of Plant Pathology, University of Agricultural Sciences, \\ Raichur-584104, Karnataka, India \\ *Corresponding author
}

\begin{tabular}{|c|c|}
\hline & A B S T R A C T \\
\hline & oeffica \\
\hline Keywords & $\begin{array}{l}\text { of fungicides (both solo and combination products) against stem rot disease of paddy. } \\
\text { Different fungicides were tested either as seed treatment (ST) seedling dip (SD) foliar sprav }\end{array}$ \\
\hline Stem Rot, Seed & (FS) or in combinations. Disease was measured in 0-9 standard evaluation scale and scores \\
\hline $\begin{array}{l}\text { Treatment, Seedling } \\
\text { Dip, Thifluzamide }\end{array}$ & were transformed into percent disease index (PDI). PDI of Kharif 2014 and Kharif 2015 \\
\hline 24 SC, Thiophanate & were pooled to get the mean PDI. Among the different treatments, ST with carbendazim at \\
\hline Methyl & (mean PDI) which was on par with another treatment comprises ST with carbendazim at \\
\hline Article Info & $2 \mathrm{~g} / \mathrm{kg}$ of seed + FS with Thiophanate Methyl $70 \mathrm{WP}$ at $1.5 \mathrm{~g} / \mathrm{l}$ (mean PDI 18.7). Significant \\
\hline $\begin{array}{l}\text { Accepted: } \\
\text { 26 September } 2017 \\
\text { Available Online: } \\
10 \text { October } 2017\end{array}$ & $\begin{array}{l}\text { ST with carbendazim at } 2 \mathrm{~g} / \mathrm{kg} \text { of seed }+\mathrm{FS} \text { with Thifluzamide } 24 \mathrm{SC}(0.75 \mathrm{ml} / \mathrm{l}) \text { which was } \\
\text { statistically on par with another treatment comprises ST with carbendazim at } 2 \mathrm{~g} / \mathrm{kg} \text { of seed }+ \\
\text { FS with Thiophanate Methyl } 70 \mathrm{WP} \text { at } 1.5 \mathrm{~g} / \mathrm{l}(50.3 \mathrm{q} / \mathrm{h}) \text { whereas, other treatments recorded } \\
\text { the vield in the range of } 34.8-44.6 \mathrm{a} / \mathrm{ha} \text {. }\end{array}$ \\
\hline
\end{tabular}

\section{Introduction}

Rice (Oryza sativa L.) is a staple food in many countries and food security to millions of population in the world and is one of the major food crops of India. More than $90 \%$ of the world's rice is grown and consumed in Asia where $60 \%$ of the earth's people live (Kole, 2006). Under field condition, the productivity of rice is affected by many biotic and abiotic factors. Among the different biotic constraints, diseases caused by fungal pathogens such as leaf blast, neck blast, sheath blight, sheath rot, false smut and stem rot cause significant damage in irrigated rice (Jackson et al., 1977; Bonman et al., 1991;
Kindo and Tiwari, 2015). Stem rot of rice caused by Sclerotium oryzae is becoming a serious problem of rice cultivation in the Indian subcontinent (Singh et al., 2002).

The causal agent was first described from Italy in the sclerotial form and was named $S$. oryzae Catt. (Cattaneo, 1876). In Karnataka, this disease occurred in epidemic form during 2012-13 and yield loss up to $30 \%$ was reported on paddy cultivar BPT5204 in North eastern part of Karnataka (Pramesh and Guruprasad, 2014). This disease was also reported to be the major constraint for paddy 
cultivation in Andra Pradesh state in recent years (Gopika et al., 2016).

For management of this disease under field condition many reports are available which describes cultural and biological methods (Keim and Webster, 1973; Cintas and Webster, 2001; Phurailatpam et al., 2014; Gopika et al., 2016). Although, cultural and biological methods are environmentally safe, their use is limited only as protectants and are cannot be used under epidemic condition. Several fungicides such as Benomyl, Edifenphos, Thiophanate Methyl, Propiconozole have been found to be effective in reducing stem rot disease severity under field condition (Singh et al., 2002; Kumar et al., 2003; Gopika et al., 2016). Recently we have reported a combination fungicide TAQAT 75\% WP (Captan 70\% + Hexaconazole 5\%) for effective management of stem rot under field condition (Pramesh et al., 2017). In the present study we have tested the efficacy of different fungicides and different modes of application for the management of stem rot disease under field condition.

\section{Materials and Methods}

\section{Layout, fungicides and crop establishment}

A field experiment was conducted in randomized complete block design (RCBD) to evaluate the bio-efficacy of fungicides (solo and combination products) in different combinations of application modes (ST, SD, FS or together) against stem rot disease of paddy at the experimental fields of Agricultural Research Station, Gangavathi, Karnataka $\left(5.4319^{\circ} \mathrm{N}, 76.5315^{\circ} \mathrm{E}\right)$ during Kharif 2014 and Kharif 2015. A popular rice variety BPT5204 which is susceptible to stem rot diseases was used for the study. For both seasons, seeds were sown in the month of July and planted in August. Before sowing, seeds for treatment 1-8 were treated with carbendazim at $2 \mathrm{~g} / \mathrm{kg}$ of seed and seeds for treatment 9 and 10 were sown without any treatment (Table 1).

The land was prepared by puddling method by applying one ploughing followed by two ploughing after one week. The experiment comprises ten treatments with three replications each with a plot size of $5 \times 4 \mathrm{~m}$ each for all treatments (Table 1). For treatment 2-8, seedlings were planted in experimental plots without SD, whereas, seedlings for treatment 1 and 9 were dipped in carbendazim at $2 \mathrm{~g} / \mathrm{l}$ before transplanting (Table 1). All standard agronomic practices were followed except using higher nitrogenous $\left(200 \mathrm{~kg} \mathrm{ha}^{-1)}\right.$ and lower pottasic $\left(50 \mathrm{~kg} \mathrm{ha}^{-1}\right)$ fertilizer dose than the normal dose $\left(\mathrm{N}_{2}: \mathrm{P}_{2} \mathrm{O}_{5}: \mathrm{K}_{2} \mathrm{O}:: 150: 75: 75\right)$. Bio-efficacy was evaluated after spraying all the test chemicals

\section{Disease assessment and statistical analysis}

Fifteen days after the fungicide application disease assessment was carried out. Disease severity was measured based on 0-9 scale (SES, IRRI, 1980). Further, the scored data was converted into per cent disease index (PDI) using formula given below. The data on the yield were recorded by marking $3 \times 2 \mathrm{~m}$ section within each plot using a wire frame as described by Seebold et al., (2004) and tillers within the frame were cut and harvested in order to determine the yield. Subsequently, the data on disease severity and yield parameters were subjected to appropriate statistical analysis.

PDI $=[($ Sum of the scores) $/$ (Number of Observation $X$ Highest Number in Rating Scale)] x 100

\section{Results and Discussion}

Stem rot disease of rice is a soil borne disease and causes crop damage from tillering stage 
to till harvest of the crop. Several reports are available on cultural and biological method of disease management under field condition (Keim and Webster, 1973; Cintas and Webster, 2001; Phurailatpam et al., 2014; Gopika et al., 2016).

Although, cultural and biological methods are environmentally safe, their use is limited only as protectants and cannot be used under epidemic condition. Several fungicides in solo formulation such as Benomyl, Edifenphos, Thiophanate Methyl, Propiconozole have been reported to be effective in reducing stem rot disease under field condition (Singh et al., 2002; Kumar et al., 2003; Gopika et al., 2016). In the present study, we have tested many solo and combi-products have been tested by combining ST, SD and FS method of application.

Data obtained from Kharif 2014 and Kharif 2015 indicated that treatment comprising ST with carbendazim at $2 \mathrm{~g} / \mathrm{kg}$ of seed + FS with Thifluzamide $24 \mathrm{SC}$ at $0.75 \mathrm{ml} / 1$ has significantly reduced the stem rot disease severity by recording lowest PDI of 15.15 (mean PDI) which is statistically on par with another treatment which comprises ST with carbendazim at $2 \mathrm{~g} / \mathrm{kg}$ of seed $+\mathrm{FS}$ with Thiophanate Methyl $70 \mathrm{WP}$ at $1.5 \mathrm{~g} / \mathrm{l}$ (mean PDI 18.7).

Previous studies reported the effectiveness of fungicides based on foliar application only and here we are reporting the combination of seed treatment with foliar application could be more effective compare to the single type of application (table 1). Inclusion of seed treatment in our study was because of the fact that many stem rot disease epidemics are observed in nursery and also in the seedling stage of direct seeded rice (based on survey and farmers opinion, unpublished data). The treatment comprising ST alone or SD alone or combination of ST and SD recorded more disease severity compare to the treatments having foliar application (Table 1) suggesting the requirement of fungicide spray after tillering stage to protect the crop. Effectiveness of Thiophanate Methyl in reducing stem rot disease was described previously (Phurailatpam et al., 2014) and here we are reporting its efficacy in combination with ST of carbendazim.

Reduced disease severity due to fungicide application was reflected in the final grain yield of the crop. Pooled yield data from Kharif 2014 and Kharif 2015 showed the significant increase in grain yield $(51.6 \mathrm{q} / \mathrm{h})$ in the plots treated with combination of ST with carbendazim at $2 \mathrm{~g} / \mathrm{kg}$ of seed $+\mathrm{FS}$ with Thifluzamide $24 \mathrm{SC}(0.75 \mathrm{ml} / \mathrm{l})$ which was statistically on par with the treatment comprises ST with carbendazim at $2 \mathrm{~g} / \mathrm{kg}$ of seed + FS with Thiophanate Methyl 70 WP at $1.5 \mathrm{~g} / 1(50.3 \mathrm{q} / \mathrm{h})$ whereas, other treatments recorded the yield in the range of 34.8-44.6/ha (Table 2).

Our results are in conformity with those of previous publication where, fungicides application increases the yield of rice (Sood and Kapoor, 1997; Tirmali et al., 2001; Prabhu et al., 2003, Usman et al., 2009; Naik et al., 2012; Bhuvaneshwari and Raju, 2012; Bag et al., 2016; Pramesh et al., 2016 a \& b). The increased yield is mainly due to reduced disease severity of stem rot disease of rice.

For successful management of rice stem rot disease under field condition fungicides are essential as there were no resistant cultivars are available and also the biological and cultural method are in efficient under severe epidemic condition.

Thus, in present situation cultural practices combined with seed treatment and foliar spray of fungicide is the most efficient and economical practice to manage the disease. 
Table.1 Bio-efficacy of different fungicides and different mode of application treatments tested against Stem rot disease under field condition

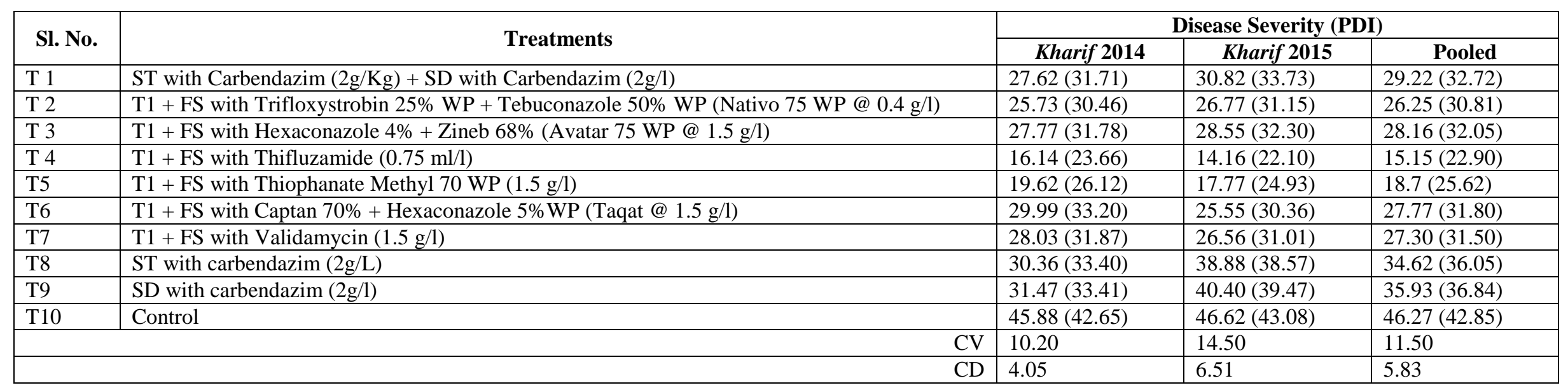

Table.2 Effect of different fungicide treatment of grain yield

\begin{tabular}{|c|c|c|c|c|}
\hline \multirow[t]{2}{*}{ Sl. No. } & \multirow[t]{2}{*}{ Treatments } & \multicolumn{3}{|c|}{ Yield $(\mathbf{Q} / \mathrm{h})$} \\
\hline & & 2014 & 2015 & Pooled \\
\hline $\mathrm{T} 1$ & ST with Carbendazim $(2 \mathrm{~g} / \mathrm{Kg})+\mathrm{SD}$ with Carbendazim $(2 \mathrm{~g} / \mathrm{l})$ & 46.1 & 43.1 & 44.6 \\
\hline $\mathrm{T} 2$ & $\begin{array}{l}\text { T1 + FS with Trifloxystrobin 25\% WP + Tebuconazole 50\% WP } \\
\text { (Nativo } 75 \text { WP @ } 0.4 \mathrm{~g} / \mathrm{l} \text { ) }\end{array}$ & 43.5 & 40.5 & 42.0 \\
\hline T 3 & $\begin{array}{l}\text { T1 + FS with Hexaconazole 4\% + Zineb 68\% (Avatar 75 WP @ } 1.5 \\
\text { g/l) }\end{array}$ & 46.5 & 43.5 & 45.0 \\
\hline $\mathrm{T} 4$ & T1 + FS with Thifluzamide $(0.75 \mathrm{ml} / \mathrm{l})$ & 52.3 & 51.0 & 51.6 \\
\hline T5 & T1 + FS with Thiophanate Methyl 70 WP (1.5 g/l) & 51.5 & 49.1 & 50.3 \\
\hline T6 & T1 + FS with Captan 70\% + Hexaconazole 5\%WP (Taqat @ 1.5 g/l) & 40.5 & 41.0 & 40.7 \\
\hline $\mathrm{T} 7$ & T1 + FS with Validamycin $(1.5 \mathrm{~g} / \mathrm{l})$ & 41.5 & 39.5 & 40.5 \\
\hline T8 & ST with carbendazim $(2 \mathrm{~g} / \mathrm{L})$ & 38.8 & 36.0 & 37.4 \\
\hline T9 & SD with carbendazim $(2 \mathrm{~g} / \mathrm{l})$ & 41.1 & 35.1 & 38.1 \\
\hline T10 & Control & 35.5 & 34.0 & 34.8 \\
\hline & $\mathrm{CV}$ & 13.46 & 12.21 & 12.45 \\
\hline & $\mathrm{CD}$ & 4.80 & 5.05 & 4.85 \\
\hline
\end{tabular}


In the present investigation we are reporting the bioefficacy of fungicides such as carbendazim at $2 \mathrm{~g} / \mathrm{kg}$ of seed (as seed treatment) followed by the foliar application of either Thifluzamide $24 \mathrm{SC}$ at $0.75 \mathrm{ml} / 1$ or Thiophanate Methyl $70 \mathrm{WP}$ at1.5 $\mathrm{g} / \mathrm{l}$ for management of stem rot disease of paddy under field condition.

\section{Acknowledgment}

This project was funded by the research and development grant from the department of Agriculture, Gov. of Karnataka (Project no. Ab.Ac. 5280). We are also thankful to Director of Research, UAS, Raichur for providing the necessary financial and work facilities.

\section{References}

Bag, M. K., Yadav, M. and Mukherjee, A. K., 2016. Bioefficacy of Strobilurin Based Fungicides against Rice Sheath Blight Disease. Transcriptomics. 4:128.

Bhaktavatsalam, G., Satyanarayana, K., Reddy, A. P. K. and John, V. T., 1978. Evaluation of sheath blight resistance in rice. International Rice Research Newsletter 3: 9-10.

Bhuvaneswari, V., and Raju, K. S., 2012. Efficacy of New Combination Fungicide against Rice Sheath Blight Caused by Rhizoctonia solani (Kuhn). Journal of Rice Research. 5 (1 \& 2).

Bonman, J. M., Estrada, B. A., Kim, C. K., Ra, D. S. and Lee, E. J., 1991. Assessment of blast disease and yield loss in susceptible and partially resistant rice cultivars in two irrigated low land environments. Plant Disease. 75: 462466.

Cattaneo, A., 1876. Sullo Sclerotium oryzae nouvo parasite vegetable che ha devasto nel corrente anno molte risaje di lombardia e del Novarese. Rediconti R.
Lombard., Milano. 2ser 9: 801-807.

Cintas, N. A., and Webster, R. K., 2001. Effects of Rice Straw Management on Sclerotium oryzae Inoculum, Stem Rot Severity, and Yield of Rice in California. Plant Disease. 85 (11).

Gopika, K., Jagadeeshwar, R., Rao, V. K. and Vijayalakshmi, K., 2016. Salient resarch findings on rice stem rot disease (Sclerotiumoryzaecatt.) and its management. International Journal of Plant, Animal and Environmental Sciences. 6(1).

Jackson, L. F., Webster, R. K., Wick, C. M., Bolstad, J. and Wilkerson, J. A., 1997. Chemical control of stem rot of rice in California. Phytophathology. 67:11551158.

Keim, R., and Webster, R. K. 1973. Nitrogen fertilization and severity of stem rot of rice. Phytopathology. 64: 178-183.

Kindo, D., and Tiwari, P. K., 2015. Efficacy of fungicides for management of sheath rot disease in rice under field conditions. Plant Archives. 15 (1):119120.

Kole, C., 2006. Cereals and millets (Vol. 1): Springer. http://dx.doi.org/10.1007/9783-540-34389-9.

Naik, G. R., Naik, G. B., Naik, B. T. and Naik, K. R., 2012. Fungicidal management of leaf blast disease in rice. Global Journal Bio science and Biotechnology. 1 (1): 18-21.

Phurailatpam S., Devi, T. and Sushma, S., 2014. Management of stem rot of rice (Sclerotium oryzae) using fungicides and biocontrol agents. Indian Journal of Plant Protection. 42(1):68-70.

Prabhu, A. S., Filipp, M. C. and Zimmermann, F. J. P., 2003. Cultivar response to fungicide application in relation to rice blast control, productivity and sustainability. Pesq. Agropec. Bras, Brasilia. 38:11-17.

Pramesh, D., and Guruprasad, G. S., 2014. 
Stem rot disease of rice: an emerging disease threatening rice production in Karnataka. In National conference on "Emerging challenges and opportunities in biotic and abiotic stress management (ECOBASM-2014) during Dec 15-18 at DRR, Hyderabad.

Pramesh, D., Maruti, Muniraju, K. M., Mallikarjun, K., Guruprasad, G. S., Mahantashivayogayya, K., Reddy, B. G. M., Gowdar, S. B. and Chethana, B. S., 2016. Bio-efficacy of a Combination Fungicide against Blast and Sheath Blight Disease of Paddy. Journal of Experimental Agriculture International. 14(4): $1-8$

Pramesh, D., Nataraj, K., Guruprasad, G. S., Mahantashivayogayya, K. and Reddy, B. G. M., 2016. Evaluation of a new strobilurin group of fungicide for the management of blast disease of paddy. American Journal of Experimental Agri. 13(5): 1-6.

Pramesh, D., Saddamhusen, A., Muniraju, K. M., and Kirana Kumara, M., 2017. A
Combination Fungicide for the Management of Sheath Blight, Sheath Rot and Stem Rot Diseases of Paddy. International Journal of Current Microbiology and Applied Sciences (In press)

Singh, R., Kumar, A. and Jalali, B. L., 2002. Variability, predisposing factors and management of stem rot caused by Sclerotium oryzae, An Overview. Annual Review of Plant Pathology. 1: 275-289.

Sood, G. K., and Kapoor, A. S., 1997. Efficacy of new fungicides in the management of rice blast. Plant Disease Research. 12:140-142.

Tirmali, A. M., Latake, S. B. and Bendra, N. J., 2001. Evaluation of new fungicides for control of blast disease of rice. Journal of Maharashtra Agricultural University. 26:197-198.

Usman, G. M., Wakil, W. Sahi, S. T. and Saleemil, Y., 2009. Influence of various fungicides on the management of rice blast disease. Mycopathology. 7: 29-34.

\section{How to cite this article:}

Pramesh D., Saddamhusen Alase, K.M. Muniraju and Kirana Kumara, M. 2017. Management of Stem Rot Disease of Paddy Using Fungicides. Int.J.Curr.Microbiol.App.Sci. 6(10): 30463051. doi: https://doi.org/10.20546/ijcmas.2017.610.358 